\title{
GENDER AND JEWISH LAW
}

\author{
Lisa Fishbayn Joffe*
}

\begin{abstract}
This essay analyses the development of feminist critiques of Jewish law, suggesting that slow progress in addressing issues of women's inequality under Jewish law through traditional mechanisms of legal criticism has led to greater focus on the jurisgenerative role of alternative rituals. Contemporary Jewish feminist legal thought identifies creativity and innovation in Jewish marital and divorce practices as a powerful tool of legal change, as important as the production of analyses of legal texts.
\end{abstract}

This brief paper will focus on the development of feminist critiques of Jewish law through the lens of changing approaches to understanding and responding to women's inequality under Jewish laws of divorce. Although the consent of both parties is required to complete a Jewish divorce, husbands enjoy disproportionate power to initiate or thwart the divorce process. While effective remedies exist to assist a husband whose wife refuses to receive a divorce, women whose husbands refuse to grant one may face a choice between becoming an agunah (עגונה), chained to a dead marriage, or acceding to extortionate demands in order to secure their freedom.

I suggest that slow progress in "finding a halakhic way" to address the agunah issue through traditional mechanisms of legal criticism has led to greater focus on the jurisgenerative role of alternative rituals. Contemporary Jewish feminist legal thought treats creativity and innovation in Jewish marital and divorce practices as a powerful tool of legal change, as important as the production of analyses of legal texts.

As with secular feminist legal theory, an early focus in this field was on the identification of bodies of Jewish law relating to women and reflection on what they can teach us about the way women are perceived and governed by these texts. For the most part, women appear as objects of study and control; more rarely as subjects explaining, developing or interrogating law.

Writing in 1974, Judith Hauptman described how the biblical model in Deuteronomy 24:1, which gives a man unfettered discretion to dismiss his wife should she fail to please him, was softened by talmudic rules. These allowed a rabbinical court to compel a man to divorce his wife if she declared that she found him repulsive or if she could invoke limited grounds relating to cruel treatment, denial of conjugal rights or affliction with an unpalatable skin disease. Hauptman's focus was on describing the very dramatic inequalities between men and women under Jewish law, but emphasizing ways in which the rabbis demonstrated concern for women's plight by surrounding the biblical law with rules that made

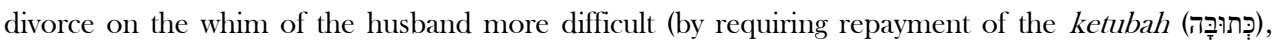
adequate notice and documentary proof of the divorce) and provided greater protections for the abandoned wife by relaxing rules of evidence where the testimony might tend to demonstrate that the husband was deceased.

While the rules remain discriminatory, Hauptman stressed the structural model in classical

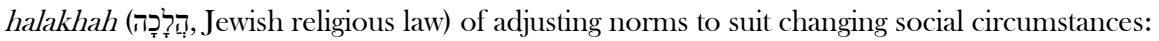

The implication for contemporary life of the conclusions reached here is that, as a result of the great changes in the technological age and woman's increasing sense of her own value and her potential contribution to society at large, a re-examination of the legal institutions and social structures dictated by rabbinic literature is

\footnotetext{
* Director of the Hadassah-Brandeis Institute, Brandeis University, Waltham, Massachusetts, US. Email: fishbaynjoffe@brandeis.edu

${ }^{1}$ To quote Blu Greenberg, the slow movement towards solutions for agunot (עגונות, plural of agunah) "bespeaks a lack of rabbinic will to find a halakhic way." Blu Greenberg, On Women and Judaism: A View from Tradition (Philadelphia: Jewish Publication Society of America, 1998), 142.
} 
urgently needed. All traces of legal and social discrimination against women - which usually reflect an outdated social structure-should be discarded. ${ }^{2}$

Hauptman also notes that while the Talmud (תלמוד, oral version of the Torah) tells an official story of women's essential nature as meek, mild and servile, it also includes a counter-narrative of powerful women like Bruriah (and Yalta) who reject these roles and offer wise counsel and interpretation of the laws of their community.

Listening to women's voices as a tool for understanding the true nature of halakhah was also reflected in programs of consciousness-raising where women could share their stories of get (ט) based extortion and getrefusal through the popular Jewish and secular press and in academic publications. ${ }^{3}$

Some theorists have sought solutions to the agunah problem in creative redeployment of accepted halakhic approaches to dissolve marriages. Aviad Hacohen, in The Tears of the Oppressed, recommended remedies based on kiddushei ta'ut (קידושי טעות), marriage transactions premised on a fundamental mistake. ' Others despair of finding solutions for existing cases of get refusal but support the prospective adoption of prenuptial agreements that would allow rabbinical courts to intervene on behalf of women. The Agunah Research Unit led by Professor Bernard Jackson, published a series of studies recommending conditional marriage. ${ }^{5}$ Shlomo Riskin suggested incorporating a commitment to pay a specified amount of maintenance to the wife from the time of separation until the get is delivered. Michael Broyde has proposed adoption of a marriage contract that combines various remedies as a belt and suspenders approach.'

Jewish feminist legal theorists and activists query whether such remedies can provide widespread relief for this gendered disadvantage. The use of these remedies has not been widely adopted. When they are used, they may be confined to their facts without precedential value or delivered in confidence so that other litigants cannot benefit. Those rabbinical courts that do use these remedies are subject to castigation from other rabbinical authorities and the validity of gittin (גיטין, plural of get) delivered under these circumstances is called into doubt. ${ }^{8}$ Many versions of the prenuptial agreement have the effect of transferring power over divorce from the husband to the rabbinical courts, rather than equalizing power between husband and wife."

Rachel Adler, in her paradigm shifting work Engendering.Judaism, ${ }^{10}$ also uses the method of identifying egalitarian solutions through redeploying doctrines approved in Jewish legal sources. However, she does not seek to tinker around the edges while leaving the fundamental inequality at the heart of Jewish marriage intact. Rather, she seeks to transform the form of marriage from unilateral acquisition of the wife by the husband, which requires his consent to part with what he has acquired, to a marital form based on legal partnership, Brit Ahuvim (ברית אהובים, Lover's Covenant). "' On this model,

\footnotetext{
${ }^{2}$ Judith Hauptman, "Images of Women in the Talmud," in Rosemary Radford Ruether, ed., Religion and Sexism: Images of Woman in the Jewish and Christian Traditions (New York: Simon and Schuster, 1974), 210.

${ }^{3}$ See for example, Jack Nusan Porter, ed., Women in Chains: A Sourcebook on the Agunah (Northvale: J. Aronson, 1995). For an account of the history of these campaigns, see Susan Aranoff and Rivka Haut, The Wed-Locked Agunot: Orthodox.Jewish Women Chained to Dead Marriages (Jefferson: McFarland \& Company, Inc., 2015). 2004).

${ }^{5}$ Bernard S. Jackson, Agunah: The Manchester Analysis, vol. 1 (Manchester, UK: Deborah Charles Publications, 2011).

Shlomo Riskin, The Jewish Woman's Right to Divorce: The Halakhic History and a Solution for the Agunah (Jersey City: Ktav Publishing House Inc., 2006), 140.

Michael Broyde, "A Proposed Tripartite Agreement to Solve Some Agunah Problems: A Solution without Any Innovations," Jewish Law Association Studies XX: The Manchester Conference Volume (2010): 1.

${ }^{8}$ See for example the unsuccessful attempt by the Israeli Rabbinate to secure standing to retroactively challenge the validity of a divorce issued by private rabbinical court in Sfat granting a get zikui זיכוי גט (in his best interests) on behalf of a man in an irreversible coma. Rachel Levmore, “Confusing Developments in Israel's Rabbinical Courts,” Jerusalem Post, November 21, 2016.

${ }^{9}$ Susan Weiss, "Prenups Meant to Solve the Problem of the Agunah: Toward Compensation, Not 'Mediation'," Nashim: A Journal of Jewish Women's Studies and Gender Studies, Special Issue on New Sociological and Historical Perspectives on Jewish Divorce, Lisa Fishbayn Joffe, guest editor, 31 (Spring - Fall 2017).

${ }^{10}$ Rachel Adler, Engendering Judaism: An Inclusive Theology and Ethics (Jerusalem: The Jewish Publication Society, 1998).

${ }^{11}$ Other alternative models for relationships which are recognized by Jewish law but do not give rise to the need for delivery of a get to affect their dissolution include Derekh Kiddushin (דרך קידושין, a purposefully contracted marriage-like relationship) or mutual
} 
the spouses acquire an interest in the marital partnership, not in each other's persons. The partnership can be dissolved at the instance of either party.

Adler's work is of interest not merely because she puts traditional legal materials to innovative use, but also because she propounds a model for halakhic legal change that gives significance to the work that Jewish feminists have been doing both in re-interpreting Jewish law and in creating alternative Jewish rituals. These rituals are not an alternative to legal transformation but one of the important instrumentalities for bringing it about. Adler does this by adapting American critical legal theory to the cause of halakhic law reform.

In Anglo-American secular legal theory, the doctrine of legal positivism differentiates law from non-legal moral claims. Laws do not derive their validity from being an expression of natural law or moral rights. Rather, they are valid if they were posited or enacted by whatever legitimate authority is recognized by the community in which they operate. In America, that is the tri-partite model of the executive, legislative and judiciary set out in the Constitution and refined through case law. In Jewish law, that is the biblical and talmudic texts and the set of procedures and norms deployed by medieval and modern poskim to apply it to new situations.

Both systems of law face the task of distinguishing legitimate from illegitimate interpretations of the law. They start from the experiential premise that it is hard to be certain how to apply a law to new situations simply by analysing the law itself and the cases to which it has been applied. Sometimes there is a clearly preferable answer, but in more challenging cases, these legal materials are open to multiple legitimate interpretations.

Jewish feminist legal theorists have looked to secular legal theory for models of how to legitimate their alternate interpretations of Jewish law. How can a feminist re-interpretation of marriage and divorce possibly be legitimate when it is inconsistent with so many of the details and fundamental premises of Jewish family law?

Rachel Adler, Tamar Ross and Ronit Irshai ${ }^{12}$ have all found the work of Robert Cover to be very useful in this regard. In order to explain why, I will contrast Cover's approach with that of Ronald Dworkin, perhaps the best known liberal legal positivist of the twentieth century. Dworkin argued for a model of law as integrity in which a legitimate interpretation is one which provides a coherent continuation to the ongoing narrative a legal community tells about itself through its legal materials. It demonstrates integrity by identifying a fit between an account of this history and of the trajectory of moral values prevailing in the society. Thus, Dworkin explains the legitimacy of the landmark 1954 decision in Brown vs. Board of Education in which the Supreme Court of the United State struck down race-based school segregation, as shaped by judicial understandings of "ethical attitudes that were widespread in the community...that racial segregation was wrong in principle." ${ }^{\prime 3}$

However, Dworkin leaves the determination of what constitutes the relevant ethical beliefs that prevail in the community solely in the hands of judges. Dworkin suggests that: "most judges will be like other people in their community," a problematic view that does not take into account the contested nature of these values and the unrepresentative demographic pool from which these judges have been drawn.

For Jewish legal feminists, Robert Cover offers a better model of legitimate legal change that treats the law reform projects of less empowered elements within the community as capable of creating nascent legal norms. According to Cover, law is not only made by judges and legislators but also by the actions and commitments of all those who participate in articulating and living the same communal legal

vows. For a detailed discussion, see Gail Labovitz, “'With Righteousness And With Justice': To Create Equitable Jewish Divorce, Create Equitable Jewish Marriage," Nashim: A Journal of Jewish Women's Studies and Gender Studies, Special Issue on New Sociological and Historical Perspectives on Jewish Divorce, Lisa Fishbayn Joffe, guest editor, 31 (Spring - Fall 2017).

${ }^{12}$ Ronit Irshai, "Towards Building a Gender Critical Approach to the Philosophy of Jewish Law (Halakhah)," Journal of Feminist Studies in Religion 26/2 (October 2010): 55-77.

${ }^{13}$ Ronald Dworkin, Law's Empire (Cambridge: The Belknap Press of Harvard University Press, 1986), 388.

${ }^{14}$ Dworkin, Law's Empire, 256. Recent political controversy in the United States over the nomination of a Justice to the Supreme Court to replace the late Justice Scalia makes clear that this is not a widely held belief there. 
narrative. ${ }^{15}$ This means that the interpretive forays and new rituals created by Jewish feminists can be characterized as effecting a material change in the Jewish normative universe.

By means of feminist jurisgenesis, we can bridge that gap [between the world we inhabit and the one we imagine] and regenerate a nomos, a world of legal meaning in which the stories, dreams and revelations of Jewish women and men are fully and complexly integrated. ${ }^{16}$

Tamar Ross sums it up like this:

The meaning of the law that is established by such acts of commitment "counts" as a legitimate interpretation not because something in the text makes it so, nor because the community's authoritative bodies hegemonically declare it so. Public acceptance is "proof" of the truth of the interpretations the community adopts simply because such acceptance is what enables an underlying narrative to hold us in the grip of its perspective in a way that gives substance and body to all the other justifications that are then applied...It enables him to transfer the criteria for the determination of legal meaning from the realm of the legal establishment to the realm of the community of practitioners at large. ${ }^{17}$

Using Cover's model, the work of contemporary Jewish legal feminists can be seen in a new light. ${ }^{18}$ They play an immediate role in creating new cultural norms regarding equality in marriage and divorce. The discussion and adoption of alternative marital forms which reject the model of acquisition is creating an alternate legal norm. The creation of new religious rituals to mark significant moments in women's lives or to mark gender transitions are constructing new legal norms.

The effective modelling of new legal norms is perhaps most clearly demonstrated in the campaign to promote the signing of the Rabbinical Council of America halakhic prenuptial agreement, promoted by the Organization for the Resolution of Agunot. This campaign is conducted online, through lobbying, post-nup signing parties and through educational events on university campuses. The pre-nup is rarely enforced in court, ${ }^{19}$ but has had an effect in changing the moral landscape regarding marriage in the Modern Orthodox community. Many rabbis will not perform marriages without it; it is celebrated and read as part of the marriage festivities and young couples have begun to expect that the husband will take this step to surrender his entitlement to withhold divorce without consequence as a matter of course. ${ }^{20}$ It works without being enforced in court because it shapes the preferences and expectations of the couple, their family and the wider community. It is part of an emergent theme in the ongoing narrative of Jewish legal meaning.

\footnotetext{
${ }^{15}$ Robert Cover, "Nomos and Narrative," in Martha Minow, et al., eds., Narrative, Violence and the Law: The Essays of Robert Cover (Ann Arbor: University of Michigan Press, 1995), 95-145, 101.

${ }^{16}$ Adler, Engendering Judaism: An Inclusive Theology and Ethics, 35.

${ }^{17}$ Tamar Ross, Expanding the Palace of Torah: Orthodoxy and Feminism (Waltham: Brandeis University Press, 2004), 153.

${ }^{18}$ David Ellenson, "To Reshape the World: Interpretation, Renewal and Feminist Approaches to Jewish Law and Legal Ruling in America and Israel," Journal of Jewish Ethics 2/2 (2016): 38.

${ }^{19}$ Although it has survived a First Amendment challenge in a case of first impression in Connecticut. See Light v. Light, 55 Conn. L. Rptr. 145 (Conn. Super. Ct. 2012).

${ }^{20}$ Bernard Jackson also argues that these alternative rituals have a role to play in creating legal change, by creating pressure on rabbinical authorities to adopt the conditional marriage agreement in order to win back couples who may be choosing to avoid kiddushin (קידושין, betrothal) in favour of Derekh kiddushin. Jackson, “Agunah: The Manchester Analysis," 286.
} 


\section{BIBLIOGRAPHY}

Adler, Rachel. Engendering Judaism: An Inclusive Theology and Ethics. Jerusalem: The Jewish Publication Society, 1998.

Aranoff, Susan, and Rivka Haut. The Wed-Locked Agunot: OrthodoxJewish Women Chained to Dead Marriages. Jefferson: McFarland \& Company, Inc., 2015.

Broyde, Michael. "A Proposed Tripartite Agreement to Solve Some Agunah Problems: A Solution without Any Innovations." Jewish Law Association Studies XX: The Manchester Conference Volume (2010): 1-15.

Cover, Robert. "Nomos and Narrative," in Martha Minow, et al., eds., Narrative, Violence and the Law: The Essays of Robert Cover, 95-145. Ann Arbor: University of Michigan Press, 1995.

Dworkin, Ronald. Law's Empire. Cambridge: The Belknap Press of Harvard University Press, 1986.

Ellenson, David. "To Reshape the World: Interpretation, Renewal and Feminist Approaches to Jewish Law and Legal Ruling in America and Israel." Journal of Jewish Ethics 2/2 (2016): 38-63.

Greenberg, Blu. On Women and Judaism: A View from Tradition. Philadelphia: Jewish Publication Society of America, 1998.

Hacohen, Aviad. The Tears of the Oppressed: An Examination of the Agunah Problem. Jersey City: Ktav Publishing House Inc., 2004.

Hauptman, Judith. "Images of Women in the Talmud," in Rosemary Radford Ruether, ed., Religion and Sexism: Images of Woman in the Jewish and Christian Traditions. New York: Simon and Schuster, 1974.

Irshai, Ronit. "Towards Building a Gender Critical Approach to the Philosophy of Jewish Law (Halakhah)." Journal of Feminist Studies in Religion 26/2 (October 2010): 55-77.

Jackson, Bernard S. Agunah: The Manchester Analysis, vol. 1. Manchester: Deborah Charles Publications, 2011.

Labovitz, Gail. "'With Righteousness And With Justice': To Create Equitable Jewish Divorce, Create Equitable Jewish Marriage.” Nashim: A Journal of Jewish Women's Studies and Gender Studies, Special Issue on New Sociological and Historical Perspectives on Jewish Divorce, Lisa Fishbayn Joffe, guest editor, 31 (Spring - Fall 2017): 91-122.

Levmore, Rachel. "Confusing Developments in Israel's Rabbinical Courts." Jerusalem Post, November 21, 2016.

Porter, Jack Nusan, ed. Women in Chains: A Sourcebook on the Agunah. Northvale: J. Aronson, 1995.

Riskin, Shlomo. The Jewish Woman's Right to Divorce: The Halakhic History and a Solution for the Agunah. Jersey City: Ktav Publishing House Inc., 2006.

Ross, Tamar. Expanding the Palace of Torah: Orthodoxy and Feminism. Waltham: Brandeis University Press, 2004.

Weiss, Susan. "Prenups Meant to Solve the Problem of the Agunah: Toward Compensation, Not 'Mediation'." Nashim: A Journal of Jewish Women's Studies and Gender Studies, Special Issue on New Sociological and Historical Perspectives on Jewish Divorce, Lisa Fishbayn Joffe, guest editor, 31 (Spring - Fall 2017): 61-90. 